\title{
A NEW ROMAN SARCOPHAGUS FROM KOMÁROM-ESZTERGOM COUNTY
}

\author{
PÉTER KOVÁCS
}

\author{
Pázmány Péter Catholic University \\ Egyetem u. 1, H-2087 Piliscsaba, Hungary \\ kovacs.peter@btk.ppke.hu
}

\begin{abstract}
Abstact: In the Museum of Tata there is an unpublished Roman sarcophagus. Because of the hardly legible inscription it has been unpublished for decades. The sarcophagus was erected by a former beneficiarius to his wife and daughter. The structure of the inscription is very unusual with two clauses because the veteran had bought the sarcophagus when his wife was still alive, later he together with his children buried them both into the sarcophagus. Because of the damaged part two restoration possibilities have been proposed. The sarcophagus was made in a local workshop of Brigetio. The inscription can be dated to the middle of the $3^{\text {rd }}$ century but before the reform of Gallienus in the 260s, as still a senatorial legatus legionis was mentioned.
\end{abstract}

Keywords: epigraphy of Roman Pannonia, sarcophagus, Brigetio

During the editorial works of the re-edition of the Corpus Inscriptionum Latinarum III Pannonia several unpublished Roman inscribed stone monuments have recently been edited. A greater part of them can be found in the collections of the Museums of Tata ${ }^{1}$ and Esztergom. ${ }^{2}$ In the court of the museum of Tata another unpublished sarcophagus can be found. Because of the hardly legible inscription it has been unpublished for decades. In this paper I intend to deal with this stone monument. ${ }^{3}$

Sarcophagus without lid (Figs 1-3). Limestone, height: 56, width: 212, depth: $89 \mathrm{~cm}$. It is damaged in several parts. Traces of mortar clearly show that the sarcophagus was found in secondary use. The epigraphic field is framed by a cymatium $(42 \times 127 \mathrm{~cm})$. The field is re-carved and damaged in several parts, esp. in the middle, which makes the second and third lines hardly intelligible. Few traces of the letters of the earlier text can also seen. Beside the epigraphic field naked, winged young Erotes with torches can be seen standing in a niche. The carelessly carved letters are 4 (lines 1 and 3-4) and $3 \mathrm{~cm}$ high (lines 2 and 5). No interpunctions can be observed between the words, sure ET (and ME) ligatures can be seen only in lines 3 and 4. Horizontal hastae can be observed above the numerals in line 3. The narrow and oblique letters and lines are carelessly carved, no ordination can be observed. Between the letters $\mathrm{M}$ and $\mathrm{D}$ in line 1 an unidentifiable sign (similar to a late cursive Q) can be observed in the middle (it cannot be interpreted as a corrupted hedera) that probably did not belong to the inscription. ${ }^{4}$ Unknown provenance (based on the text: Brigetio or its territorium). It can be found in the Kuny Domokos Museum at Tata (without an InvNr), where I have studied and photographed the sarcophagus several times in the years 2009 and 2013.

${ }^{1}$ P. KovÁCS-B. LŐRINCZ: Neue römische Inschriften aus Komitat Komárom-Esztergom I. ZPE 174 (2010) 277-287.

${ }^{2}$ P. KOVÁCS-B. LŐRINCZ: Neue römische Inschriften aus Komitat Komárom-Esztergom II. ZPE 179 (2011) 247-270 = Újabb római kori feliratok Komárom-Esztergom megyéből II. Studia Epigraphica Pannonica 3 (2011) 66-99.

${ }^{3}$ I wish to thank the Directory of the Museum of Tata for the permission and Dr. Sándor Petényi for his help. I am also indebted DOI: 10.1556/072.2016.67.1.5 to Ortolf and Friderike Harl for their excellent new photos that made possible to correct my restoration.

${ }^{4}$ In most cases only the adjective Manes I(nferi) or the accusative s(acrum) can be observed between the letters D and M. The letter Q is attested here only once in an Italian funerary inscription (which cannot be expanded either): NSA 1940, 197 (Civitavecchia/ Centumcellae).

Acta Archaeologica Academiae Scientiarum Hungaricae 67 (2016) 129-30 0001-5210/\$20.00 C 2016 Akadémiai Kiadó, Budapest 


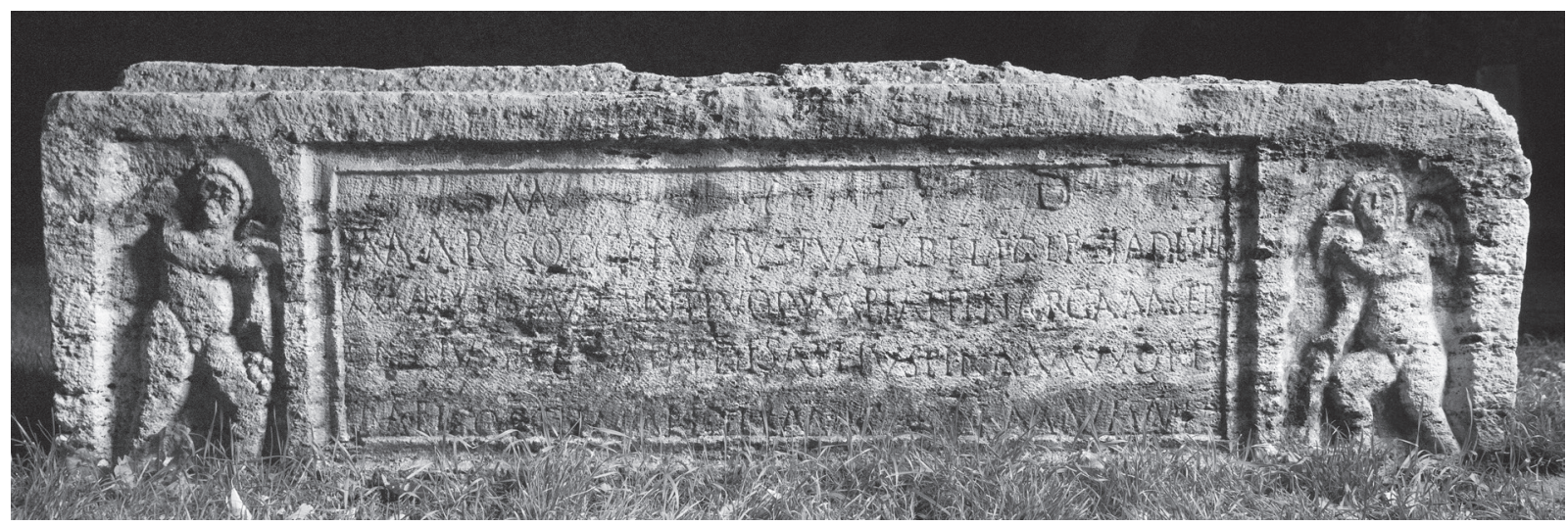

Fig. 1 The sarcophagus (Photo: Ortolf Harl)

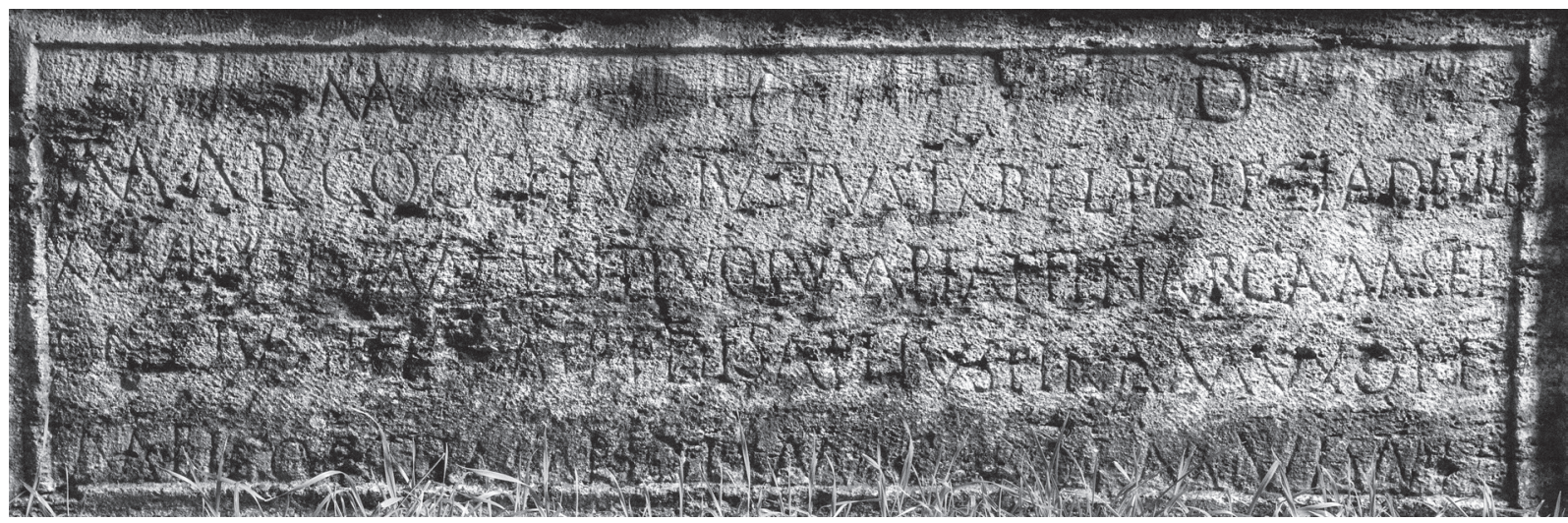

Fig. 2 The inscription (Photo: Ortolf Harl)

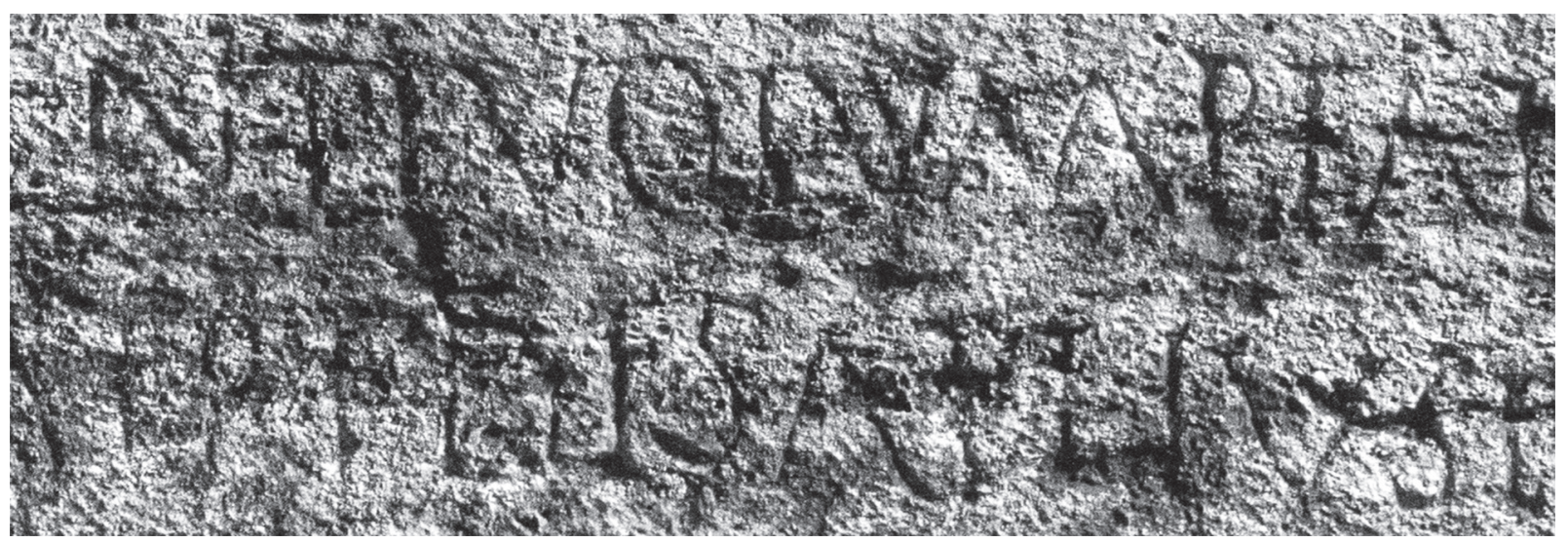

Fig. 3 Detail of lines 2-3 (Photo: Ortolf Harl) 
The following text and damaged (partly re-carved) letters can be seen in the epigraphic field:

\author{
M(anibus) $D($ is) \\ Mar(cus) Cocceius Iustus b(ene)f(iciarius) leg(ati) leg(ionis) I adi(utricis) \\ stip(endiorum) \\ $X X V I+O++T M+E N T I$ votum PIA ++ in arcam sep- \\ OLIR iuss $++++++I S$ Ael(iam) Iustinam uxore- \\ 5 \\ $m$ et Cocceia $(m)$ Marcellam filiam vivus.
}

The inscription was erected by the veteran M. Cocceius Iustus, who had earlier been the beneficiarius of the legate of the legio I adiutrix in Brigetio. He buried two female members of his family into the sarcophagus (mentioned as arca). Several beneficiarii of the legionary commanders were attested from Brigetio earlier: RIU 554, 560, 589 (bf praefecti), ${ }^{5}$ who could have served several more years as active soldiers as in this case (because of their special mission). ${ }^{6} \mathrm{~A}$ few Cocceii are attested from Brigetio and its territory: RIU 379, 480, 764. On the other hand, the cognomina Iustus, Iustina, frequently used in Pannonia, are attested in this region, too: RIU 542, 718, as well as 696. ${ }^{7}$ The same can be observed in the case of the cognomen Marcell(in)a: Marcellus/a: RIU 738, 779, TRH 111, Marcellina: RIU 441, 547, 557, 738. ${ }^{8}$ The members of the family were earlier unknown and it cannot be excluded that Cocceia Marcia also belonged to the family who erected an altar dedicated to Baltis in Brigetio (RIU 379). Aelia Iustina's name is attested in Pannonia twice, but these Iustinae had no connection to Brigetio (Carnuntum: AÉp 2010, 1261, Lugio: RIU 1031).

The text contains few abbreviations because of the unusual formulation of the inscription. A few mistakes of the stone-cutter (mistakenly carved oblique hasta in line 3 between $\mathrm{V}$ and $\mathrm{M}$ ) or vulgar Latin phenomena can be observed in the text, most of the names and words are written in full. Only the most frequent and widely known abbreviations were used, as in the case of the legio I adiutrix. The last I of the infinitive sepeliri and the last $\mathrm{M}$ of a gentile name in accusative are omitted because of the same following letters of the verb and the cognomen: SEPOLIR IVSSERVNT and COCCEIA MARCELLAM. The vulgar form sepolire/sepoltura/sepolchrum (O instead of E) can be observed in very few epigraphic texts from the $3^{\text {rd }}$ century (e.g. CIL X 1193, HEp 502, CLEAfr 82, Tronto p. 19, 193). ${ }^{9}$ The formula DM was used in reverse order as Manibus Dis, which is also unusual but attested in Pannonia, too: e.g. CIL III 15183 (Andautonia). The praenomen Marcus was also abbreviated in an unusual way: Mar(cus) (cp. e.g. CIL III 11111, RIU 1501, Tit. Aq. 1016 in Pannonia). The adjective vivus (concerning the veteran) was placed at the end of the inscription (probably added later) (cp. e.g. CIL IX 3898). Based on the conjunction et it is clear that in line 3, after the length of the military service of the veteran, at least two active verbs were used. Based on the nominative it is also certain that the inscription was erected by the veteran (therefore his age was not mentioned in line 3). ${ }^{10}$ The impersonal passive construction sepeliri iussit/iusserunt does not necessarily mean that the family did not live in the place of burial (i.e. in Brigetio). It is extremely rarely attested in funerary inscriptions in the entire Roman Empire (in case of sarcophagi the verb condere is more frequent: cp. CIL V 3643: in arcam condidit): CIL VI 41025 (but see also another funerary text from Gaul: CIL XII 2836 (Ugernum) ... quam sarcofago posito ... sepelivit). In Pannonia earlier only the construction debuerat ... sepelire was attested (RIU 1522). The verb iubere had to be used in the plural: iusserunt as in the middle of line 4 the formula pater fili(i)s can be observed. The veteran and his other children erected the sarcophagus obviously to his family members, based on the word

${ }^{5}$ J. Отт: Die Beneficiarier. Untersuchungen zu ihrer Stellung innerhalb der Rangordnung des römischen Heeres und zu ihrer Funktion. Historia Einzelschriften 92. Stuttgart 1995, 71-73; PWRE XII (1925) 1394; B. LổINCZ: Legio I adiutrix. In: Y. Le Bohec (éd.): Les légions de Rome sous le Haut-Empire. Actes du Congrès de Lyon, 17-19 septembre, 1998. Collection du Centre d'Études Romaines et Gallo-Romaines. Nouvelle série 20. Lyon 2000, 151-158.

${ }^{6}$ G. Preuss: Soziale und wirtschaftliche Stellung der Beneficiarier in der provinzialen Gesellschaft. In: E. Schallmayer (Hrsg.): Der römische Weihebezirk von Osterburken II. Kolloquium 1990 und paläobotanische-osteologische Untersuchungen. Stuttgart 1994, 265 266 und 268
${ }^{7}$ B. LŐRINCZ: Onomasticon provinciarum Europae Latinarum. Vol. II. Wien 1999, 209-210.

${ }^{8}$ B. LÖRINCZ: Onomasticon provinciarum Europae Latinarum. Vol. III. Wien 2000, 54-55.

${ }^{9}$ CIL III p. 2571, 2676, H. MiHĂESCU: La langue latine dans le sud-est de l'Europe. Bucureşti-Paris 1978, 180, No. 125.

${ }^{10}$ There are several cases in which the age and the length of the military service appear in reverse order: e.g. in Pannonia: RIU 275, 581, 660, 694, 718, 741, 792, 946, 1303, 1307, 1552a, Tit. Aq. $541,545,548,583,644,647,678,707,775,983,1019$ 
uxor primarily to his wife, therefore in the damaged part of line 3 only his wife was mentioned, probably with adjectives in the dative. Her name can be found in line 4:Ael(ia) Iustina in the accusative. The first adjective begins with an $\mathrm{M}$ (most probably with a ligature $\mathrm{ME}$ ) that can probably be completed as merenti. This is not as frequent as the usual formula benemerenti, but it occurs in funerary inscriptions several times (Pannonian cases together with the verb posuit merenti: CIL III 14358 ${ }^{13 a}$, RIU 1217, 1407, Tit. Aq. 686). This means that the veteran bought the sarcophagus when his wife was still alive. This fact also explains why the inscription contained two clauses. After the word votum there was a second adjective beginning with a P. It can very likely be completed as pia in the dative, as it is one of the most frequent adjectives in consorts in a funerary context (Pannonian cases: e.g. CIL III 11305, RIU 369, 1262). The two adjectives (merens and pia) very rarely occur together: e.g. CIL VI 14089 together with other ones. On the other hand, the letters PIAE can also be restored as the adverb pi\{a\}e. In this case it concerns to the veteran's pious act (i.e. buying the sarcophagus). The length of the military service in line 2 had to be followed by the first predicate (that contained only five letters). Among the heavily damaged letters an $\mathrm{O}$ and the last $\mathrm{T}$ can clearly be seen, therefore it must be restored as pos(u)it. The vulgar Latin phenomenon is very typical in the $3^{\text {rd }}$ century Pannonian inscriptions. ${ }^{11}$

The missing word in the questioned part of line 3 can only be read and restored as votum. This word, which was extremely frequent in religious use, also occurs in funerary inscriptions with a meaning 'vow' made to the Manes (mainly on grave-altars) (a Pannonian case: RIU 662), and it can also be found in the expression contra votum (especially in early Christian inscriptions) (in Pannonia: ILS 9093). In these cases votum refers to the death that came against hopes and wishes in order to show the pain of the survivors. ${ }^{12}$ In this sense votum can mean simply mean a promise, in postclassical use the marriage vow and in a transferred sense the marriage itself, too. ${ }^{13}$ In the case of the sarcophagus the word should be interpreted as the object of the clause besides the verb posuit. The expression votum ponere frequently occurs in votive inscriptions, too. Can the word also denote the grave monument? Besides the formula Dis Manibus, grave-altars almost always end with the formula votum solvit libens merito, which can also be observed on gravestones (e.g. IScM V 27). The word votum can also be seen after the dedication Dis Manibus (obviously instead of sacrum: e.g. IRPLeon 261). Some grave monuments were erected ex voto: e.g. CIL XI 1791, ICUR 4834 = ILCV 4164 (sepulcrum / haec tibi pro meritis pendo merentia voto), Vindobona: AÉp 2002, 1169. In early Christian funerary texts the expression votum solvere or reddere can be observed several times (e.g. ICUR $8750=\mathrm{ILCV} 3248$ Alexandro fratri bene merenti votum merenti fratres / reddiderunt). In our case these verbs can be excluded, because the damaged predicate in line 3 must be restored as posuit. ${ }^{14}$ In this context votum can mean the vow/promise made to the deceased or a votive offering to a martyr, and the funerary monument, too. ${ }^{15}$ This use of votum can also be observed in the Danubian provinces: Poetovio: CIL III $4098^{2}=$ AIJ 444 = ILCV 1922 votum Pusinnio posuit, Dacia / Berethalom: CIL III 1617 = IDR III 4, 187 = ILCV 1920 Ego Zeno/vius (!) vot/um posui. In the former case the verb can be completed as solvit votum and the veteran had promised his wife earlier to bury her into the sarcophagus, in the latter case the votum was the sarcophagus itself.

Based on this, the latter restoration of the new sarcophagus cannot be excluded either, but the former one seems to be more plausible, as there are hardly any parallels in a pagan funerary context, especially in the Danubian provinces.

${ }^{11}$ J. Herman: Posit (=posuit) et questions connexes dans les insriptions pannoniennes. ActaAntHung 9 (1961) 321-331; B. FEHÉR: Pannonia latin nyelvtörténete. Budapest 2007, 291.

${ }^{12}$ U. EHMIG: Adversus vota / contra votum. Epigraphica 74 (2012) 201-215; U. EHMIG: Pro \& contra. Erfüllte und unerfüllte Gelübde in lateinischen Inschriften. Historische Zeitschrift 296 (2013) 321-328.

${ }^{13}$ Ausführliches Lateinisch-Deutsches Wörterbuch. Unveränderter Nachdruck der achten verbesserten und vermehrten $\mathrm{Au}$ flage von H. GEORGES. Bd. II. Darmstadt 1998 (Reprint der Ausgabe Hannover 1913-1918), 3555-3556; CH. T. LewIS-CH. ShORT (ed.): A Latin Dictionary. Oxford 1879, 2014-2015; P. G. W. Glare (ed.): Oxford Latin Dictionary. Oxford 1968, 2103-2104.

Acta Archaeologica Academiae Scientiarum Hungaricae 67, 2016
${ }^{14}$ On the various uses of the word votum in a Christian context, see e.g. ILCV 1905-1934. See also O. MARUCCHI: Christian Epigraphy. An Elementary Treatise. Oxford 1912, 187-188.

${ }^{15}$ Cp. e.g. Rome: ICUR $23398=\operatorname{ILCV} 1921$ botu(m) (!) po/sue(ru)nt marture (!) Felicitati; ICUR $1529=$ ILCV 1906 ... Aurelius Marcus / botum (!) quod / tristis / promisit / filiae [---]; Aquileia: ILCV 1933 = Inscr. Aq. 3005 [- - -]ius Caramantius / (a)evum cum cumpare (!) sua / digni merentibus / vel dig/nem sibi dunc / semul bene\{m\} / meriti bixeru/nt (!) (h)unc botum (!) / paraberunt (!) si/bi pariter in se. 
The hardly intelligible, complex inscription can be restored as follows:

\author{
$M$ (anibus) $D($ is $)$ \\ Mar(cus) Cocceius Iustus b(ene)f(iciarius) leg(ati) leg(ionis) I adi(utricis) \\ stip(endiorum) \\ XXVI posit (!) merenti votum piae or pi\{a\}e et in arcam sepolir( \\ i) (!) iusseru[nt p]ater filis Ael(iam) Iustinam uxore- \\ $5 \quad m$ et Cocceia $(m)$ Marcellam filiam vivus.
}

The veteran first bought the sarcophagus and the place of the burial (locus sepulturae: AÉp 1994, 1372) for his wife when she was still alive, later he together with his other children buried her and their daughter here. The funerary text was completed at this time. The simple stone monument was made in a local workshop in/near Brigetio that prepared similar sarcophagi with Eros figures during the entire $3^{\text {rd }}$ century, but esp. in the first half of the century. ${ }^{16}$ Based on this fact, the re-use of the sarcophagus, the funerary text and the unusual abbreviations the inscription can be dated to the middle of the $3^{\text {rd }}$ century but before the reform of Gallienus in the 260 s, as still a senatorial legatus legionis was mentioned.

${ }^{16}$ E. Pochmarski: Zur Ikonographie und Chronologie der römischen Sarkophage aus Brigetio. BudRég 34 (2001) 201-202, 205-206, Nr. 1-17. 